\title{
Conference report from 13th European Conference on Precision Agriculture (ECPA)
}

\author{
A. Nyéki $i^{*}$ D, A. J. Kovács, M. Neményi and G. Milics
}

\begin{abstract}
This is a report on the 13th European Conference on Precision Agriculture (ECPA) that took place between 18 and 22, July at the location of the University of Public Service in Budapest, Hungary. The theme of the Conference was the "Adoption of innovative precision agriculture technologies and solutions". Due to the pandemic, the conference was a hybrid event. The two societies - the International Society of Precision Agriculture and the Hungarian Society of Precision Agriculture - had contributed to the event. The international conference was mainly attended by academic researchers, university instructors, company executives and farmers. The event comprised five plenary and 22 scientific sessions.
\end{abstract}

Keywords: Precision agriculture, Sustainable environment, Digitalization, Innovation technologies, Healthy food production

The main objectives of the conference were to support science, foster innovations and provide opportunities to connect to international knowledge networks. Besides, the presentation and discussion of scientific results which can be applied in practice and can contribute to environmental sustainability. The adoption of precision agriculture would keep the balance between competitiveness and safeguarding our Planet. Digitalization offers many possibilities to increase all aspects of sustainability in agricultural production and traceable food.

The organizing committee was led by Gabor Milics $(\mathrm{PhD})$, the founding president of the Hungarian Society of Precision Agriculture. For this conference, 400 participants coming from 26 countries from all continents had registered. 116 scientific papers in 25 topics and 20 poster abstracts were presented. The conference papers in Precision Agriculture'21-edited by: John. V. Stafford-was made available on Wageningen Academic Publisher website (https://www.wageningenacademic.com/doi/

\footnotetext{
*Correspondence: nyeki.aniko@sze.hu

Faculty of Agricultural and Food Sciences, Department of Biosystems and Food Engineering, Széchenyi István University, Vár 2.,

Mosonmagyaróvár 9200, Hungary
}

book/10.3920/978-90-8686-916-9). By recommendation of conference committee, selected and improved papers were invited for in the international journal "Precision Agriculture".

The range of session themes can be divided into the following topics:

- Precision agriculture

- Precision horticulture

- Precision crop protection

- Precision viticulture

- Proximal and remote sensing of soil and crop

- Applications of unnamed aerial systems

- Satellite-based applications for precision agriculture

- Site-specific nutrient, lime and seed management

- Drainage optimization and variable rate irrigation

- Geostatistics, mapping and spatial data analysis

- Robotics, guidance and automation

- Adoption of precision agriculture

- Education in precision agriculture

- On-farm experimentation with site-specific technologies

- Software and mobile apps for precision agriculture

- Decision support for precision agriculture

\section{Springer Open}

(c) The Author(s) 2021. Open Access This article is licensed under a Creative Commons Attribution 4.0 International License, which permits use, sharing, adaptation, distribution and reproduction in any medium or format, as long as you give appropriate credit to the original author(s) and the source, provide a link to the Creative Commons licence, and indicate if changes were made. The images or other third party material in this article are included in the article's Creative Commons licence, unless indicated otherwise in a credit line to the material. If material is not included in the article's Creative Commons licence and your intended use is not permitted by statutory regulation or exceeds the permitted use, you will need to obtain permission directly from the copyright holder. To view a copy of this licence, visit http://creativecommons.org/licenses/by/4.0/. 
- Miscellaneous

Twenty-two sessions were organized with presentations and gathered large groups of participants. Besides, five international experts have presented the keynote lectures.

- Prof. Raj Khosla of Kansas State University (USA) delivered a plenary presentation, titled "Farming the data-New paradigm in precision agriculture". Spatial and temporal heterogeneity was emphasized to manage agro-ecosystems and translating those into better decision models, using remote sensing and other geo-spatial tools to enhance production, resource use efficiency, profitability, and sustainability of managed agro-ecosystems. The on-going precision nitrogen management work has demonstrated significant reductions in nitrous oxide $\left(\mathrm{N}_{2} \mathrm{O}\right)$ emissions on farm fields. Besides, the research is focusing on the nextgeneration of soil-moisture and soil-nitrate sensors that are inexpensive, passive (battery-less), small, and bio-degradable.

- Prof. Dimitrios Moshou (AUTH and Head of the Laboratory of Agricultural Engineering, Greece) spoke on "Deep learning in agriculture". This research includes the theory and applications of artificial intelligence and deep learning and their synergy/explanation with bio-inspired information processing, neuroscience, self-organization. The interests focus on intelligent control, pattern recognition, data fusion, food safety, traceability, and cognitive robotics. The application areas include crop and food monitoring, mechatronics and non-destructive quality control and monitoring of bio-products and crops.

- Prof. Bruno Tisseyre is professor in precision agriculture at the Institut Agro-Montpellier SupAgro (National Institute for Higher Education in Agriculture and Natural Resources, France) and James Taylor, who is research director with INRAE (Information Technologies for the Agriculture of Tomorrow Research Unit) in Montpellier, discussed the precision viticulture with focus on the innovation issues and precision technologies adoption. The presentation was related to the development of methods (e.g. spatial data fusion, to characterize the spatial variability and to assess the ability to manage the within-field variability, spatial extrapolation, remote sensing...) and the increase of research impact of precision vineyard.

- Jacob van den Borne, owner of Van den Borne Potatoes, is an arable farmer in the south of The Netherlands. Precision farming technologies are used with a strong belief this way the next-generation farm- ers can really start to understand location-specific growing processes and minimize environmental impact. The company was founded in 1952 by Jan van den Borne. Over the last 45 years the business has expanded rapidly and now grows 550 hectares of potatoes, 50 hectares of sugar beet and 300 hectares of maize. The company data are available through his website VanDenBorneAardappelen.com, flies drones over his fields, uses satellite data and is researching, analysing and visualizing soil scans and yield data.

- Finally, Prof. Simon Pearson, the Director of the Lincoln Institute for Agri-Food Technology at University of Lincoln (UK), discussed the "Engineering the future of Agri-robotics". This research in the field of agri-technology is bringing together academic and industrial experts who are striving to improve technological, environmental and human capital aspects of the food industry. This research embraces a diverse range of agri-technology applications including robotic systems, automation and design for manufacture of integrated e-hubs for agricultural vehicles. It is seeking to develop agri-robotics to drive productivity across the agri-food sector, including crop harvesting, phenotyping and crop care. Professor Pearson has brought together a network of experts to investigate how artificial intelligence, data analytics and emerging technologies can enhance the digitalization of the UK food supply chain.

Apart from the scientific sessions, several side events were organized. Participants gained insight into precision agriculture technology solutions adopted and applied on the field through the example of large Hungarian farming company, Keve Ltd. As another side event, precision workshop was organized by the Embassy of the Kingdom of the Netherlands in Hungary and the Netherlands Agricultural Network. The aim of the workshop was to discuss about practical applications of precision agriculture in the field, transitioning into the precision model and what this paradigm means in everyday practice and in business.

In the opinion of the authors, the most valuable results of the conference was that it allowed the precision agriculture community to focus on specific topics covering all aspects of practices, while discovering what colleagues are working on, enabling synergies and cooperation. The results of the precision conference are its contribution to the integration of sustainable agriculture and environment. The presented research is in line with the economic stability, development and sustainability.

Based on these technologies and innovations, energy and water-saving methods would be applied, release of Greenhouse Gas (GHG) emissions could be lessened and 
the amount of pesticides and fertilizers could be reduced. The role of informatics, robotics, and data processing are playing greater role in agri-food research and practice. These are the main objectives both in agriculture and in other sectors (e.g. automobile industry) in order to gain sustainable and cleaner production.

\section{Acknowledgements}

The Hungarian Ministry of Agriculture is acknowledged for their financial support to hold the conference. Many thanks to International Society of Precision Agriculture and the Hungarian Society of Precision Agriculture for organizing. The authors thank the "Thematic Excellence Program—National Challenges Subprogram-Complex Precision Crop Production Research at Széchenyi István University (TKP2020-NKA-14)" project.

\section{Authors' contributions}

NyA wrote a first version of the manuscript; all authors contributed to the optimization of the manuscript. All authors read and approved the final manuscript.

\section{Funding}

Not applicable.
Availability of data and materials

Not applicable.

\section{Declarations}

Ethics approval and consent to participate

Not applicable.

\section{Consent for publication}

Not applicable.

\section{Competing interests}

The authors declare that they have no competing interests.

Received: 17 August 2021 Accepted: 23 September 2021

Published online: 09 October 2021

\section{Publisher's Note}

Springer Nature remains neutral with regard to jurisdictional claims in published maps and institutional affiliations.

\section{Submit your manuscript to a SpringerOpen ${ }^{\odot}$ journal and benefit from:}

- Convenient online submission

- Rigorous peer review

- Open access: articles freely available online

- High visibility within the field

- Retaining the copyright to your article

Submit your next manuscript at $\boldsymbol{\nabla}$ springeropen.com 